\title{
PROTEIN ENERGY WASTING IN PERITONEAL DIALYSIS PATIENTS
}

\author{
Emina Kostić ${ }^{1}$, Jelena Kostić ${ }^{1}$, Milena Stefanović2 ${ }^{2}$ Branka Mitić ${ }^{1}$
}

\begin{abstract}
Among many risk factors that affect outcomes of patients with chronic kidney disease and the ones on maintenance dialysis, the state of metabolic and nutritional derangements called "protein-energy wasting" (PEW) plays a major role. Most guidelines recommend that nutritional status should be evaluated by using a combination of valid, complementary measures.

The aims of this study were to analyze body composition, to detect the presence of undernutrition, and to establish the relationship between parameters of body composition, body mass index (BMI) and laboratory parameters routinely used as indicators of nutritional status in PD patients. Body composition was examined by a body composition monitor (BCM) that expresses body weight in terms of lean tissue mass (LTM) and fat tissue mass (FTM). BMI is defined as the weight in kilograms divided by the square of the height in metres $\left(\mathrm{kg} / \mathrm{m}^{2}\right)$. All the patients had blood samples taken for biochemical analysis (creatinine, albumin, cholesterol).

Our study included 37 peritoneal dialysis patients (23 female and 14 male). Our study was able to show high prevalence of undernutrition ( $56.76 \%$ of patients) expressed by low LTI, in our group of patients. Most of the patients had normal FII $(83.78 \%)$. Body mass index was not a good marker of nutritional status of our patients and according to this parameter there were no malnourished patients in our study group. The levels of creatinine and cholesterol showed positive correlation with LTM, proving to be good markers of nutritional status while the levels of albumin failed to show any correlation with other parameters of nutritional status. The 3 year follow up showed that the LTI has a positive correlation with survival.

Our conclusions are that PEW is common in dialysis patients. It should be assessed by complementary methods, and patients at risk should be treated adequately to reduce the risk of morbidity and mortality.
\end{abstract}

Acta Medica Medianae 2019;58(3):10-14.

Key words: protein energy wasting, body composition, body mass index, peritoneal dialysis

${ }^{1}$ Clinic for Nephrology, Clinical Center Niš, Serbia

2University in Niš, Medical faculty, Niš, Serbia

Contact: Emina Kostić

Blvd dr Zoran Djindjić 48, 18000 Niš, Serbia

E-mail: kosticemina@ymail.com

\section{Introduction}

Among many risk factors that affect outcomes of chronic kidney disease (CKD) patients, especially the ones with end-stage renal disease (ESRD) and on maintenance dialysis, the state of metabolic and nutritional derangements called "protein-energy wasting" (PEW) of chronic kidney disease plays a major role(1). PEW is defined as a state of gradual and non-functional loss of muscle and fat tissue, eventually resulting in cachexia. The described state is not caused only by an inadequate dietary intake but is rather the result of metabolic disturbances in chronic renal failure such as derangements in fat metabolism, acidosis, inflammation-driven catabolism, nutrient losses in the dialysate, along with endocrine disturbances, such as hyperparathyroidism, hyperglucagonemia, and peripheral insulin resistance. A number of studies have shown that PEW is related to an increased number of hospitalizations, increased morbidity, and mortality (2).

While consensus about the importance of identifying and treating malnourished dialysis patients exists (3), the assessment of their nutritional status is not simple. Over the years, many methods have been proposed to identify malnourished and wasted CKD patients. However, there is currently no single tool that can be used to identify protein-energy wasting in these patients. On the contrary, most guidelines recommend that nutritional status should be evaluated by using a combination of valid, complementary measures $(4,5)$.

The aims of this study were to analyze body composition, to detect the presence of undernutri- 
tion, and to establish the relationship between parameters of body composition, body mass index (BMI) and laboratory parameters routinely used as indicators of nutritional status in PD patients.

\section{Patients and methods}

We conducted a study in 37 patients that had been on peritoneal dialysis (PD) program in Clinical Center Niš, Clinic for Nephrology, during 2013. Survival of the patients was followed until the end of 2016. All the patients had biochemical parameters important for their nutritional assessment done (creatinine, cholesterol, and albumin). Body mass index was calculated as body weight $(\mathrm{kg})$ to square of the body height $(\mathrm{m})$ ratio. Body composition was assessed by a portable device (a body composition monitor - BCM Fresenius Medical Care D GmbH) that expresses body weight in terms of lean tissue mass (LTM) and fat tissue mass (FTM) independent of hydration status. The BCM Fresenius device measures the impedance of body tissues over wide frequency ranges and differentiates normally hydrated (NH) LTM from NH FTM regardless of the degree of extracellular fluid and it offers a reliable measure of both hydration status and nutritional status in our patients $[+]$. Undernutrition was defined as having a lean tissue index $\left(\mathrm{LTI}=\mathrm{LTM} /\right.$ height $\left.^{2}\right)$ below the $10^{\text {th }}$ percentile of a reference population derived from BCM measurements of 1000 healthy adult subjects aged 18-75. This reference population is age and gender-specific, as body composition varies throughout life and between genders (6). Measurements were taken with the patient calm, supine, and relaxed for 2 minutes after the electrodes had been attached to the hand and foot on the same side of the body. All measurements were performed by a trained nurse. Exclusion criteria were dictated by the device and included the history of a pacemaker, defibrillator, stent implantation or amputation of a major limb.

The Excel program from Microsoft Office was used for quantitative statistical analysis, and a software package was used for the tabular presentation of data. Calculations were performed using the SPSS program version 10.0. The limits of statistical significance were estimated at 0.01 or $1 \%$ and 0.05 or $5 \%$ as the default error in all analysis. Chi-squared test was used to determine whether there was a significant difference between the expected frequencies and the observed frequencies in one or more categories. Spearman's rank correlation coefficient was used as a nonparametric measure of rank correlation (statistical dependence between the rankings of two variables), and, Mann-Whitney $U$ test was used as a nonparametric test of the null hypothesis that it is equally likely that a randomly selected value from one sample will be less than or greater than a randomly selected value from a second sample.

\section{Results}

We conducted a study in 37 patients (pts), 14 (37.84\%) male and 23 (62.16\%) female, and their average age was $63.32 \pm 12.61$ years. The average age of male pts was $66.84 \pm 9.93$ years and the average age of female pts was $61.42 \pm 13.70$ years.

The frequency of patients on PD with qualitatively defined LTI and FII values is given in table 1. A slight majority of patients, 21 (56\%) had low LTI, while the rest of the study group had a normal LTI. None of them had high LTI. The majority of patients - $31(83.78 \%)$ had normal values of FTI, while 3 of them $(8.11 \%)$ had low FII, and 3 of them $(8.11 \%)$ had high FII. There were significantly more PD patients with normal than abnormal values of FTI ( $p<$ $0.001, \chi^{2}$ test) in this study.

Table 1. Qualitatively defined LTI and FTI indexes in PD patients

\begin{tabular}{|lcc|}
\hline Parameter & LTI & FTI \\
\hline \hline Normal & $16(43.24 \%)$ & $31(83.78 \%)$ \\
Low & $21(56.76 \%)$ & $3(8.11 \%)$ \\
High & & $3(8.11 \%)$ \\
\hline \hline \multicolumn{1}{|c|}{$\Sigma$} & $37(100.00 \%)$ & $37(100.00 \%)$ \\
\hline
\end{tabular}

The nutritional status of PD patients based on BMI values is shown in Table 2. Based on BMI, there were no malnourished patients in our group, while 18 of them (48.65\%) were normally nourished, and 19 of them (51.35\%) were obese.

Table 2. Nutritional status of PD patients according to BMI values

\begin{tabular}{||llr|}
\hline Nutrition & & \\
\hline \hline Normal & 18 & $(48.65 \%)$ \\
Obese & 19 & $(51.35 \%)$ \\
\hline \hline$\Sigma$ & 37 & $(100.00 \%)$ \\
\hline
\end{tabular}

Table 3 presents comparison of LTI and FTI values in adequately nourished and obese pts in PD (estimated by BMI), and the following results were established: FII values are statistically higher in obese than in normally nourished PD pts ( student ttest, $p<0.001$ ).

Table 3. Values of LTI and FTI compared to the nutrition of the PD patients

\begin{tabular}{||ccc||}
\hline & Normal weighted & Overweighted \\
& $\mathrm{n}=18$ & $\mathrm{n}=19$ \\
\hline \hline LTI & $12.03 \pm 2.20(11.60)$ & $11.19 \pm 1.94(11.40)$ \\
FTI & $8.93 \pm 2.42(9.00)$ & $15.52 \pm 4.85(14.60)$ \\
\hline
\end{tabular}

The correlation of continual values of LTI and FII with BMI is shown in Table 4. BMI shows a negative and week correlation with LTI, but a very strong and positive correlation with FII (Spearman correlation index, $\mathrm{p}<0.001$ ). 
Table 4. Correlation of BMI with LTI and FTI in PD patients

\begin{tabular}{|lcc|}
\hline & LTI & FTI \\
\hline \hline BMI & -0.23 & $0.82 * * *$ \\
\hline
\end{tabular}

There is a positive correlation between LTI and all the biochemical parameters of nutrition, but the statistically significant ones are with creatinine $(r=$ 0.34, $p<0.05)$ and cholesterol $(r=0.34$, $p<0.05)$.

There is positive but statistically non significant correlation between FTI and albumin (Table 5).

Table 5. Correlation of LTI and FTI with the biochemical parameters of nutritional status

\begin{tabular}{||ccccc|}
\hline & Creatinine & & Albumin & Chol \\
\hline \hline LTI & $0.34^{*}(r)$ & $r$ & $0.27(r)$ & $0.39^{*}(r, \rho)$ \\
FTI & $-0.12(\rho)$ & $\rho$ & $0.16(\rho)$ & $-0.30(\rho)$ \\
\hline
\end{tabular}

$*-p<0.05$,

$r$ - Pearson correlation coefficient,

$\rho$ - Spearmancorrelation coefficient

There was statistically significant positive correlation between LTI and survival in our group of pts $(p<0.01)$. On the other hand no statisticaly significant correlation was found after comparing FTI and survival (Table 6).

Table 6. The correlation of LTI and FII index and mortality in PD patients

\begin{tabular}{||ccc||}
\hline & $\begin{array}{c}\text { Survived } \\
\mathrm{n}=19\end{array}$ & Decided \\
& $\mathrm{n}=18$ \\
\hline \hline \multirow{2}{*}{ LTI } & $12.64 \pm 1.91$ & $10.49 \pm 1.68$ \\
& $(13.30)^{* *}$ & $(11.15)$ \\
FTI & $10.84 \pm 4.14$ & $13.87 \pm 5.59$ \\
& $(9.70)$ & $(12.70)$ \\
$* * \mathrm{p}<0.01$ (Mann-Whitney test) & \\
\hline
\end{tabular}

\section{Discussion}

Our study was able to show high prevalence of undernutrition, as expressed by low LTI, in our group of patients. These findings are consistent with several other studies in which the prevalence of undernutrition differed according to the method used to define nutritional status. The French study (7) which included 7123 patients, showed undernutrition in $62 \%$ of the studied population, according to the lean body mass index. Woodrow et al. (8) have also found a significantly lower LTM measured with dual X-ray absorptiometry (DXA) and bioelectrical impedance analysis (BIA) in patients with advanced chronic renal failure, peritoneal dialysis, and HD compared with the healthy group.

Body mass index has not adequately presented the nutritional status of our patients, and accord- ing to this parameter, there were no malnourished patients in our study group, while 18 of them $(48.65 \%)$ were normally nourished, and 19 of them $(51.35 \%)$ were obese. This fact supports the view that BMI does not represent an adequate parameter of nutrition for patients with chronic renal failure, as gross imbalance in fluid status in these patients may cloud the results. Also, the loss of muscle mass is characteristic in PEW; however, a relatively well-preserved fat mass still usually remains, resulting in small changes in BMI that can be disguised by imbalances in fluid homeostasis (9). Finally, BMI can't estimate the distribution of fat tissue which has significant metabolic implications.

The ability of the Body Composition Monitor to separate fat from lean tissue allowed us to examine the correlation between BMI and LTI as well as BMI and FII. In healthy subjects BMI depends on both fat and lean (muscular) tissue (10). In our patients, BMI clearly expressed the changes in the fat deposits but failed to show lean mass status. Similar results were obtained by Honda et al. (9) who have examined the relationship between BMI, body composition parameters, and PEW in 328 patients who started dialysis treatment. Their study showed high incidence of PEW in obese patients, which correlated with high FTI and low LTI, a state which is defined as "obese sarcopenia".

Biochemical parameters have an important role in routine assessment of the nutritional status of dialysis patients. The most commonly used biochemical parameters are: creatinine, albumin and cholesterol. However, many studies have shown that they are not always reliable.

In our study the level of albumin has shown no correlation with LTI and a week positive correlation with no statistical significance with FTI. These results are in line with other studies that have demonstrated the uselessness of serum albumin levels as an accurate marker of nutritional status in dialysis patients $(11,12)$. There are several reasons for that: first, the level of albumin is influenced by factors such as overhydration, proteinuria and losses into the dialysate in PD patients. Additionally, albumin has a relatively long half-life, limiting the impact of a decreased protein intake on serum concentrations (13). Also, albumin is an acute phase reactant; thus, s-albumin levels in dialysis patients are strongly associated with inflammation rather than insufficient food intake (14).

Creatinine has shown a positive and statistically significant correlation with LTI, proving to be a good marker of muscle mass. These results are in accordance with several other studies which have shown that even in stable chronic dialysis patients in whom kidney function is minimal to nonexistent serum creatinine level is a reliable surrogate marker of muscle mass $(15,16)$.

Serum cholesterol has also been proposed as an assessment criterion for malnutrition and PEW (5). Our study has shown statistically significant positive correlation between serum cholesterol levels and LTI, but no correlation between s-cholesterol and FII. Contrary to the general population (17), a high $\mathrm{s}$-cholesterol level in the CKD and dialysis population is associated with improved survival (18). 
The three year follow up of our patients showed that there was a statistically significant positive correlation between LTI and survival in our study group, while, on the other hand, no statistical significance was found after comparing FII and survival. These findings are similar to those published in the study of Slovakian population which showed that low LTI was a strong independent predictor of mortality (19).

\section{Conclusion}

Protein energy wasting is common and very significant problem in dialysis patients. It is not always easy to assess, and it usually requires complementary measures to be done. However, since it has a significant impact on our patients lives by increasing the number of hospitalizations, morbidity, and mortality it should be carefully monitored and treated when needed.

\section{References}

1. Ikizler A, Ikizler A, Cano NJ, Franch $H$, Fouque D, HimmelfarbJ, Kalantar-Zadeh K, et al. Prevention and treatment of protein energy wasting in chronic kidney disease patients: a consensus statement by the International Society of Renal Nutrition and Metabolism. Kidney Int 2013; 84:1096-107. [CrossRef] [PubMed]

2. Kovesdy CP, Kalantar-Zadeh K. Why is protein-energy wasting associated with mortality in chronic kidney disease? Semin Nephrol 2009; 29:3-14.

[CrossRef] [PubMed]

3. Steiber AL. Chronic Kidney Disease: Considerations for Nutrition Interventions. JPEN J Parenter Enteral Nutr 2014; 38(4):418-26. [CrossRef] [PubMed]

4. Clinical practice guidelines for nutrition in chronic renal failure. K/DOQI, National Kidney Foundation. Am J Kidney Dis 2000; 35(6 Suppl 2):1-140.

5. Fouque D, Kalantar-Zadeh K, Kopple J, Cano N, Chauveau $P$, Cuppari $L$, et al. A proposed nomenclature and diagnostic criteria for protein-energy wasting in acute and chronic kidney disease. Kidney Int 2008; 73(4):391. [CrossRef] [PubMed]

6. http://www.bcm-fresenius.com/23.htm.

7. Aparicio M, Cano N, Chauveau P, Azar R, Canaud B, Flory $A$, et al. Nutritional status of haemodialysis patients: a French national cooperative study. Nephrology Dialysis Transplantation 1999; 14(7):1679-86. [CrossRef] [PubMed]

8. Woodrow G, Oldroyd B, Turney JH, Tompkins L, Brownjohn AM, Smith MA. Whole body and regional body composition in patients with chronic renal failure. Nephrology Dialysis Transplantation 1996; 11(8): 1613-8. [CrossRef]

9. Honda H, Qureshi AR, Axelsson J, Heimburger O, Suliman $M E$, Barany $P$, et al. Obese sarcopenia in patients with end-stage renal disease is associated with inflammation and increased mortality. Am J Clin Nutr 2007; 86(3):633-8. [CrossRef] [PubMed]

10. WHO Expert Consultation. Appropriate body-mass index for Asian populations and its implications for policy and intervention strategies. The Lancet 2004; 363 (9403):157-63. [CrossRef] [PubMed]

11. Heimburger O, Qureshi AR, Blaner WS, Berglund L, Stenvinkel P. Hand-grip muscle strength, lean body mass, and plasma proteins as markers of nutritional status in patients with chronic renal failure close to start of dialysis therapy. Am J Kidney Dis 2000; 36 (6):1213-25. [CrossRef] [PubMed]

12. Bossola M, La Torre G, Giungi S, Tazza L, Vulpio C, Luciani G. Serum albumin, body weight and inflammatory parameters in chronic hemodialysis patients: a three-year longitudinal study. Am J Nephrol 2008; 28(3):405-12. [CrossRef] [PubMed]

13. Rothschild $M$, Oratz $M$, Schreiber $S$. Regulation of albumin metabolism. Annu Rev Med 1975; 26:91104. [CrossRef] [PubMed]

14. Kaysen G, Dubin J, Müller H, Rosales L, Levin N, Mitch $\mathrm{W}$, et al. Inflammation and reduced albumin synthesis associated with stable decline in serum albumin in hemodialysis patients. Kidney Int 2004; 65(4):140815. [CrossRef] [PubMed]

15. Noori N, Kopple JD, Kovesdy CP, Feroze U, Sim JJ, Murali SB, et al. Mid-arm muscle circumference and quality of life and survival in maintenance hemodialysis patients. Clin J Am Soc Nephrol 2010; 5:225868. [CrossRef] [PubMed]

16. Kalantar-Zadeh K, Streja E, Kovesdy CP, Oreopoulos A, Noori N, Jing J, et al. The obesity paradox and mortality associated with surrogates of body size and muscle mass in patients receiving hemodialysis. Mayo Clinic Proc 2010; 85:991-1001. [CrossRef] [PubMed]

17. Kannel WB, Castelli WP, Gordon T. Cholesterol in the prediction of atherosclerotic disease. New perspectives based on the Framingham study. Ann Intern Med 1979; 90(1):85-91. [CrossRef] [PubMed]

18. Kovesdy CP, Anderson JE, Kalantar-Zadeh K. Inverse association between lipid levels and mortality in men with chronic kidney disease who are not yet on dialysis: effects of case mix and the malnutrition-inflammation-cachexia syndrome. J Am Soc Nephrol 2007; 18(1):304-11. [CrossRef] [PubMed]

19. Rosenberger J, Kissova V, Majernikova M, Straussova Z, Boldizsar J. Body composition monitor assessing malnutrition in the hemodialysis population independently predicts mortality. Journal of Renal Nutrition 2014; 24(3):172-6. [CrossRef] [PubMed] 


\title{
Originalni rad
}

\section{GUBITAK PROTEINSKE ENERGIJE KOD BOLESNIKA PERITONEALNE DIJALIZE}

\author{
Emina Kostić ${ }^{1}$, Jelena Kostić ${ }^{1}$, Milena Stefanović ${ }^{2}$, Branka Mitić ${ }^{1}$
}

${ }^{1}$ Klinika za nefrologiju, Klinički centar Niš, Niš, Srbija

${ }^{2}$ Univerzitet u Nišu, Medicinski fakultet, Niš, Srbija

Kontakt: Emina Kostic

Bulevar dr Zorana Đinđića 48, 18000 Niš, Srbija

E-mail: kosticemina@ymail.com

Među brojnim faktorima rizika koji utiču na ishod lečenja bolesnika sa hroničnom bubrežnom slabošću i onima na dijalizi, stanje metaboličkih i nutritivnih poremećaja označeno kao "proteinsko-energetska pothranjenost" zauzima značajno mesto. Brojni vodiči predlažu da se stanje uhranjenosti naših bolesnika procenjuje kombinovanjem komplementarnih merenja.

Ciljevi ispitivanja bili su analiza telesnog sastava, utvrđivanje učestalosti pothranjenosti i korelacije između parametara telesnog sastava, indeksa telesne mase (ITM) i laboratorijskih parametara koji se najčešće koriste za procenu stanja uhranjenosti bolesnika na dijalizi. Analiza telesnog sastava vršena je na osnovu podataka dobijenih Body composition monitorom aparatom koji meri masu masnog (fat tissue mass FTM) i nemasnog (lean tissue mass LTM) tkiva. ITM je izračunavan kao odnos telesne težine u kilogramima i kvadrata visine u metrima $\left(\mathrm{kg} / \mathrm{m}^{2}\right)$. Svim bolesnicima uzimana je $\mathrm{krv}$ za opšte laboratorijske analize (kreatinin, holesterol, albumini).

$\mathrm{U}$ našem ispitivanju učestvovalo je 37 bolesnika sa programa peritonealne dijalize (23 žene i 14 muškaraca). Naše ispitivanje pokazalo je veliku učestalost pothranjenosti bolesnika $(56,76 \%)$ izraženu kroz nizak indeks nemasnog tkiva. Najveći broj bolesnika imao je normalan indeks masnog tkiva (83,78\%). Indeks telesne mase (ITM) nije se pokazao kao dobar marker nutritivnog statusa i na osnovu ovog parametra nije bilo pothranjenih bolesnika u našoj grupi. Nivo kreatinina i holesterola pokazao je pozitivnu korelaciju sa masom nemasnog tkiva, čime su se ovi parametri izdvojili kao dobri markeri nutritivnog statusa, za razliku od albumina koji nije pokazao nikakvu korelaciju sa drugim parametrima uhranjenosti. Trogodišnje praćenje ovih bolesnika pokazalo je da postoji pozitivna korelacija između indeksa nemasnog tkiva i preživljavanja bolesnika.

Naši zaključci su da je proteinsko-energetska pothranjenost česta kod bolesnika na dijalizi. Treba je procenjivati kombinovanjem komplementarnih metoda i bolesnike sa rizikom treba adekvatno lečiti kako bi se smanjio morbiditet i mortalitet.

Acta Medica Medianae 2019;58(3):10-14.

Ključne reči: proteinsko-energetska pothranjenost, telesni sastav, indeks telesne mase, peritonealna dijaliza 